\title{
Albinism in Elaphe sauromates
}

\author{
DANIEL JABLONSKI ${ }^{1 *}$, JANKO JANKOV², KIRIL BEDEV \& NIKOLAY NATCHEV ${ }^{2,4}$
}

\author{
${ }^{1}$ Department of Zoology, Comenius University in Bratislava, Ilkovičova 6, Mlynska dolina, Bratislava, Slovakia \\ ${ }^{2}$ Department of Biology, Faculty of Natural Sciences, Shumen University, Universitetska Str. 115, Shumen, Bulgaria \\ ${ }^{3}$ Field Ecology Station, Atanasovsko lake, IBER-BAS, Burgas, Bulgaria \\ ${ }^{4}$ Department for Integrative Zoology, Vienna University, Althanstrasse 14, 1090 Vienna, Austria \\ ${ }^{*}$ Corresponding author e-mail: daniel.jablonski@balcanica.cz
}

$T_{1}^{\text {he }}$ he Sarmantian Rat Snake, Elaphe sauromates (Pallas, 1814 ) is a rarely observed species from the Ponto-Caspian region. It is distributed from western-central Anatolia, through the eastern Balkan Peninsula of the northern Black Sea coast and Crimea to the western margins of Central Asia (Jablonski et al., 2019). This snake has a yellowish ground colour, often pronounced, sometimes orange-brown or very light. Characteristic is a dorsal dark pattern with transverse diamond to oval blotches. In older individuals this pattern is more diffuse. The ventral surface is often uniformly light (Schulz, 1996). Only one case of colour aberration has been recorded previously in this species and this was albinism in a $35 \mathrm{~cm}$ long immature specimen near Jambol town, ca $80 \mathrm{~km}$ west of Burgas (Petzold, 1975).

During a field survey on 12 October 2018 at 1:50 p.m. (local time), an adult $E$. sauromates was found that completely lacked intense pigmentation, the body appeared pale-yellow to light brown and the eyes scarlet (Fig. 1). The snake could not be captured for precise measurement but we noticed that it was an adult with an estimated total length around 1200 $\mathrm{mm}$. This albino individual was found on a gravel road leading from route E87 to a local wind turbine platform, between the villages Kavarna and Hadzhi Dimitar in the Varna region, north-eastern Bulgaria ( $\left.43^{\circ} 45^{\prime} 37^{\prime \prime} \mathrm{N}, 28^{\circ} 41^{\prime} 34^{\prime \prime} \mathrm{E}\right)$. The road forms an ecotone between a plant protection belt of Fraxinus excelsior and a corn field.

Interestingly, a second albino specimen of similar coloration was recorded on 30 May 2019 on the road between Kavarna and Balgarevo, again in NE Bulgaria $\left(43^{\circ} 43^{\prime} 36^{\prime \prime} \mathrm{N}, 28^{\circ}\right.$ $35^{\prime} 95^{\prime \prime}$ E) at 5:27 p.m. This location was only $5 \mathrm{~km}$ from the first and on both sides of the road were growths of Fraxinus angustifolia and fields. Temperature during the observation was about $21^{\circ} \mathrm{C}$ with weak wind. The individual was an adult with a total length of $985 \mathrm{~mm}$, tail length $205 \mathrm{~mm}$, and body weight $221 \mathrm{~g}$.

These two cases of albinism are the first reported for adult $E$. sauromates. It is considered that albino snakes are rarely encountered in nature due to predation pressure on such individuals when juvenile (see Gezova et al., 2018). Nevertheless, these two new records show that survival of albino $E$. sauromates to the adult stage in the wild is possible. This may be due to the hidden lifestyle of this species.

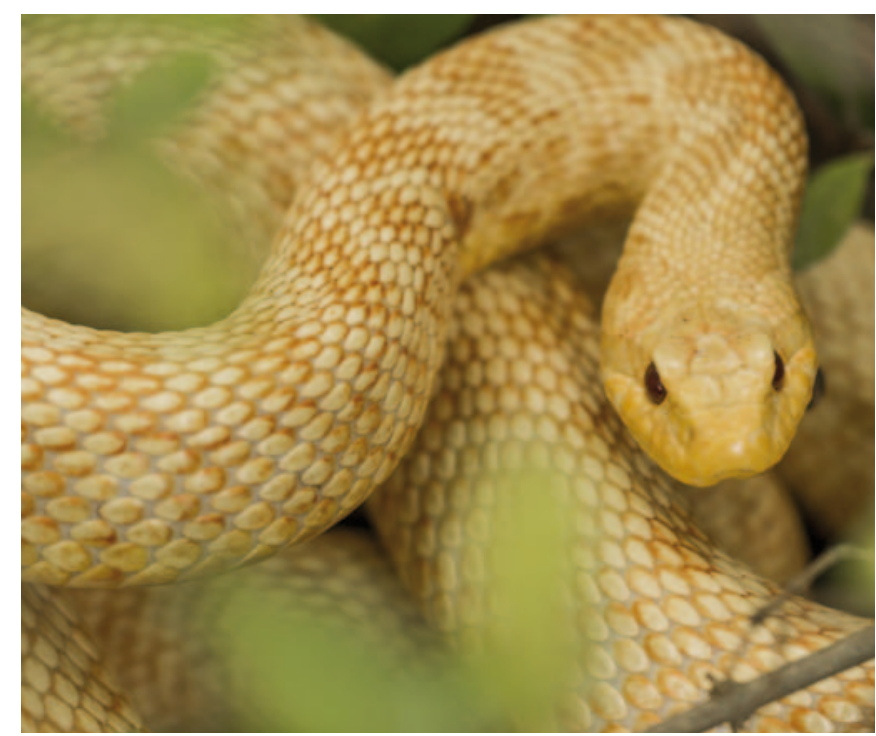

Figure 1. An albino E. sauromates found near the village of Kavarna, NE Bulgaria

\section{ACKNOWLEDGEMENTS}

This work was supported by the Slovak Research and Development agency under the contract no. APVV-15-0147 and the FNS project number RD-08-104/01.02.2019 of the Shumen University, Bulgaria.

\section{REFERENCES}

Gezova, S., Drugac, P., Purkart, A. \& Jablonski, D. (2018). Albinism in two snake species recorded from Slovakia. Russian Journal of Herpetology 25: 79-82.

Jablonski, D., Kukushkin, O.V., Avci, A., Bunyatova, S., Kumlutas, Y., Ilgaz, C., Polyakova, E., Shiryaev, K., Tuniyev, B. \& Jandzik, D. (2019). The biogeography of Elaphe sauromates (Pallas, 1814), with a description of a new rat snake species. PeerJ: 7: e6944

Petzold, H-G. (1975). Eine albinotische Vierstreifennatter, Elaphe quatuorlineata sauromates, aus Bulgarien. Salamandra 11: 113-118.

Schulz, K-D. (1996). Eine Monographie der schlangengattung Elaphe Fitzinger. Wurselen: Bushmaster Publications. 460 pp. 